\title{
PEMBELAJARAN TEKNOLOGI INFORMASI DAN KOMUNIKASI DITINJAU DARI MINAT BELAJAR
}

\author{
Syifa Fauziyah ${ }^{1}$ dan Mochamad Bruri Triyono ${ }^{2}$ \\ ${ }^{1}$ Fakultas Keguruan dan Ilmu Pendidikan Universitas Veteran Bangun Nusantara \\ ${ }^{2}$ Fakultas Teknik Universitas Negeri Yogyakarta \\ email: syifafauziyah.2017@student.uny.ac.id
}

\begin{abstract}
Abstrak
Penelitian ini bertujuan untuk mengetahui minat belajar pada saat pembelajaran teknologi informasi dan komunikasi khususnya siswa kelas X SMK ditinjau dari minat internal, minat eksternal, dan pendekatan belajar. Subjek pada penelitian ini adalah semua siswa kelas X Program Keahlian Teknik Komputer dan Jaringan di SMK Negeri 3 Yogyakarta yang berjumlah 30 siswa. Data penelitian dianalisis dengan statistik deskriptif, sedangkan metode yang digunakan untuk mengumpulkan data dalam penelitian ini menggunakan angket modifikasi skala likert. Dari hasil penelitian menunjukkan bahawa pertama, pembelajaran teknologi informasi dan komunikasi sudah dilaksanakan tetapi terdapat kendala yaitu guru mengajar hanya sebatas teori. Kedua, sebagian besar siswa memiliki minat belajar dengan kategori sedang dalam pembelajaran teknologi informasi dan komunikasi. Dengan demikian, minat belajar pada pembelajaran teknologi informasi dan komunikasi perlu ditingkatkan lagi. Ketiga peningkatan minat belajar pada pembelajaran teknologi informasi dan komunikasi dapat dilakukan dengan memadukan model pembelajaran yang sesuai sehingga siswa dapat menguasai materi baik teori ataupun praktik.
\end{abstract}

Kata kunci: pembelajaran, teknologi informasi dan komunikasi, minat belajar

\section{INFORMATION AND COMMUNICATION TECHNOLOGY LEARNING REVIEWED FROM INTEREST TO LEARN}

\begin{abstract}
This study was aimed at determining the interest in learning information and communication technology of grade $\mathrm{X}$ vocational students in terms of internal interests, external interests, and learning approaches. The subjects in this study were 30 students of class X Computer and Network Engineering Skills Program at Vocational High School 3 of Yogyakarta. The research data were analyzed using descriptive statistics, while the method used to collect the data in this study was using a Likert scale modified questionnaire. The findings show that first, learning information and communication technology has been implemented but the teacher teaches only focus on the theory. Second, most students have an interest in learning with the moderate category in learning information and communication technology. Thus, interest in learning in learning information and communication technology needs to be increased. Third, increasing interest in learning in learning information and communication technology can be done by combining appropriate learning models so that students are able to master learning material both theory and practice.
\end{abstract}

Keywords: learning, information technology and communication, learning interest 


\section{PENDAHULUAN}

Perubahan lingkungan baik dari segi sosial, budaya, ekonomi, hukum, ataupun teknologi secara tidak sadar berpengaruh dalam dunia pendidikan. Sekolah merupakan suatu lembaga yang bergerak dalam pendidikan formal memiliki peran penting dalam adaptasi siswa. Peran sekolah dalam adaptasi siswa memiliki harapan agar siswa dapat bersaing dengan kehidupan yang akan datang. Peran guru di sekolah memiliki kedudukan yang penting karena setiap hari siswa berinteraksi dengan gurunya. Namun, saat ini banyak guru yang kurang memahami perannya untuk membekali siswa di kehidupan selanjutnya. Suparman (2014, p. 14) menjelaskan bahwa guru berperan sebagai fasilitator dalam proses pembelajaran. Guru berperan memfasilitasi siswa yang tujuan akhirnya diperoleh proses dan hasil belajar siswa. Proses dan hasil belajar yang diperoleh kemudian diakumulasi dalam tiga aspek. Pada proses pebelajaran, siswa tidak hanya memperoleh aspek pengetahuan (kognitif), tetapi juga aspek sikap (afektif) dan aspek ketrampilan (psikomotorik) yang dihasilkan dari potensi siswa pada saat pembelajaran berlangsung.

Selain hasil belajar, guru hendaknya memberikan motivasi kepada siswa dalam belajar. Salah satu hal penting dan paling awal diperhatikan guru terhadap perkembangan siswa adalah minat. Rusyan (2015, p. 254) menjelaskan bahwa minat belajar adalah suatu keadaan pada mental seseorang yang menghasilkan proses yang memiliki tujuan yang jelas pada suatu situasi atau pada objek tertentu sehingga menimbulkan sesuatu yang menyenangkan dan dapat memberikan keputusan atas dirinya. Pertama, minat mencakup suatu hal tentang suatu kesukaan, kegemaran terhadap sesuatu, atau kesenangan terhadap suatu hal.
Minat belajar tidak ada dengan sendirinya. Minat belajar berasal dari berbagai faktor. Faktor-faktor tersebut yang nantinya berpengaruh pada diri seseorang. Slameto (2009, p. 43) mengatakan bahwa faktor-fator yang dapat mempengaruhi munculnya minat belajar pada diri seseorang terdiri dari; yang pertama Dorongan diri. Kedua, motif sosial. Minat yang berasal dari lingkungan sekitar seseorang. Ketiga, faktor emosional, minat mempunyai hubungan yang amat dekat dengan emosional. Seseorang memperoleh kesuksesan dari hasil kerja keras maka menimbulkan perasaan bahagia dan memperkuat minat tersebut. Namun, jika seseorang mendapatkan kegagalan, timbul perasaan tidak senang dan menghilangkan minat terhadap dirinya. Hal ini sama dengan kemampuan suatu lembaga pendidikan terhadap pemenuhan kebutuhan siswa atau mahasiswa. Apabila lembaga mampu meningkatkan kualitas, kemenarikan, dan fasilitas belajar, minat pun semakin meningkat. Hal ini diperkuat dengan hasil penelitian Surifah, Mustiati, Syaifullah, dan Bowo (2016) yang menemukan bahwa motivasi pada diri mahasiswa berpengaruh kepada minat belajar. Prodi Akuntansi terakreditasi B memiliki nilai yang lebih tinggi dan signifikan daripada Prodi Akuntansi yang terakreditasi C. Akreditasi A lebih tinggi dan signifikan daripada akreditasi $\mathrm{C}$. Keberhasilan lembaga dalam meningkatan minat dipengarui dengan kelengkapan yang ditawarkan lembaga kepada siswa.

Minat sendiri memiliki beberapa indikator untuk menunjang proses belajar. Indikator tersebut berasal dari beberapa faktor yang ada pada diri seseorang. Pertama, faktor internal yaitu faktor yang ada pada diri siswa. Pada faktor internal terdiri dari dua bentuk yaitu fisiologis dan psikologis. Fisiologi berkaitan dengan fisik seseorang dan psikologis berkaitan dengan 
kecerdasan dan bakat seseorang. Kedua, faktor eksternal yang terdiri dari lingkungan sosial dan lingkungan nonsosial yang berperan dalam menumbuhkan minat siswa. Lingkungan sosial terdiri dari keluarga, sekolah, ataupun masyarakat sedangkan lingkungan nonsosial terdiri dari materi yang diperoleh pada saat pembelajaran, alat-alat belajar, ataupun tempat tinggal. Ketiga, pendekatan belajar merupakan cara yang digunakan untuk memahami materi atau pokok bahasan tertentu dalam pembelajaran (Kawet, 2017).

Kemajuan Teknologi Informasi dan Komunikasi (TIK) yang pesat, diperlukan minat belajar yang baik pada diri seseorang. Perlu adanya penyesuaian yang mendorong seseorang untuk terus mempelajarinya. Dengan adanya pembelajaran teknologi informasi dan komunikasi diharapkan siswa dapat mengeksplor, mencari, dan menganalisis informasi yang berujung pada pertukaran informasi yang efektif dan efisien di masa yang akan datang.

Informasi yang didapat disertai tuntunan dari guru membuat siswa terus berpikir kreatif untuk mengembangkan pengetahuannya. Anshori (2017, p. 18) menyatakan bahwa manfaat yang diperoleh setelah mempelajariTIK antara lain:pertama, menyadarkan siswa terhadap potensinya dalam perkembangan TIK sehingga dapat memotivasi dan mengembangkan minatnya. Kedua, memotivasi siswa untuk siap beradaptasi terhadap perkembangan yang semakin berkembang pesat. Ketiga, mengembangkan kemampuan yang ada pada siswa dengan mengoprasikan dan mengembangkan teknologi informasi yang menarik. Keempat, manfaat mempelajari TIK adalah mengembangkan kemampuan belajar mandiri, berinisiatif, keratif, dan inovatif dalam penggunaan teknologi informasi pada saat menempuh pendidikan ataupun ketika telah bekerja.
Sekolah Menengah Kejuruan (SMK) merupakan salah satu sekolah yang mempelajari TIK. Pendidikan kejuruan saling berkaitan dengan keterampilan menggunakan alat atau mesin Nurmala (2012, p. 164). Pendidikan kejuruan merupakan perpaduan antara pengetahuan umum dan praktik, pemahaman konsep yang diterapkan dengan keterampilan, kemampuan kreatif yang menghasilkan produktivitas yang sasarannya untuk bekerja. Dengan adanya sasaran di SMK tersebut, perlu dilengkapi bekal pengetahuan tentang teknologi informasi dan komunikasi agar keahlian yang mereka miliki dapat tersalurkan di masa yang akan datang.

Di SMK terdapat mata pelajaran khusus yang mempelajari tentang TIK. Mata pelajaran yang dimaksud adalah Mata Pelajaran Simulasi dan Komunikasi Digital (SKD). Mata Pelajaran SKD diperuntukkan untuk seluruh keahlian di SMK yang menggunakan Kurikulum 2017 (Revisi Kurikulum 2013). Mata Pelajaran SKD mempelajari dan mengembangkan TIK melalui pengembangan produk digital. Sekolah yang menjadi fokus penelitian ini adalah SMK Negeri 3 Yogyakarta pada Program Keahlian Teknik Komputer dan Jaringan (TKJ) yang berjumlah 30 siswa pada Tahun Ajaran 2018/2019.

Pada saat dilakukan observasi pada tanggal 22 Februari 2019, setiap siswa dihadapkan dengan satu unit komputer yang lengkap. Di dalam kelas, tersedia layar proyektor untuk memudahkan guru mengajarkan mata pelajaran simulasi dan komunikasi digital. Lengkapnya fasilitas yang ditawarkan di sekolah akan sempurna apabila pembelajaran dilengkapi dengan model pembelajaran yang sesuai agar pembelajaran lebih inovatif. Muhson (2009) menjelaskan bahwa model pembelajaran mampu menjembatani kemampuan siswa 
baik kemampuan pengetahuan (teori) maupun keterampilan (praktik). Dengan menggunakan model pembelajaran yang diterapkan di sekolah, harapannya dapat dijadikan salah satu alternatif pemecahan masalah yang sering muncul dalam pendidikan di Indonesia yaitu rendahnya kualitas dan relevansi pendidikan.

Berdasarkan hasil wawancara kepada siswa, pembelajaran SKD kurang menarik karena guru hanya membahas secara teori. Teori yang disampaikan guru ditampilkan dalam presentasi. Guru kurang mengarahkan pada kegiatan praktik sehingga siswa merasa sangat kurang memperoleh inti dari pembelajaran tersebut. Komputer yang disediakan mengalihkan perhatian siswa daripada mata pelajaran yang berlangsung. Pada saat peneliti mengajukan beberapa pertanyaan kepada siswa terkait materi pada mata pelajaran SKD, siswa tidak dapat menjawab. Siswa merasa masih kurang pemahaman tentang pertanyaan yang diajukan. Selain itu, guru juga bersikap kaku dan monoton sehingga membuat siswa enggan mengikuti pembelajaran. Di samping kelemahan tersebut, guru memiliki pengaruh yang baik terhadap perkembangan teknologi informasi dan komunikasi dengan menampilkan slide presentasi dengan bantuan proyektor.

\section{METODE}

Jenis penelitian yang digunakan dalam penelitian ini merupakan penelitian deskriptif dengan metode kuantitatif. Subjek penelitian adalah semua siswa kelas X Program Keahlian TKJ di SMK Negeri 3 Yogyakarta yang berjumlah 30 siswa pada Tahun Ajaran 2018/2019. Metode yang digunakan dalam penelitian ini adalah metode observasi, metode wawancara, dan metode angket tentang minat siswa mempelajari Mata Pelajaran SKD. Proses penilaian pada angket tentang minat belajar siswa dalam mempelajari TIK adalah dengan bentuk modifikasi skala likert. Modifikasi skala likert bertujuan untuk mengetahui kecendrungan jawaban yang diberikan siswa. Disediakan empat buah alternatif jawaban untuk setiap butir soal yang diajukkan. Empat jawaban tersebut adalah STS (Sangat Tidak Setuju), TS (Tidak Setuju), S (Setuju), SS (Sangat Setuju).

Kisi-kisi yang digunakan untuk angket minat belajar terdiri dari faktor internal, faktor eksternal, dan pendekatan belajar. Analisis data yang digunakan pada penelitian ini adalah hasil analisis deskriptif yang meliputi hasil rata-rata pada angket minat (M), Nilai maksimal yang diperoleh dari angket minat belajar (Maks), Nilai minimal yang diperoleh dari angket minat belajar (Min), dan standar deviasi (SD). Dari data deskriptif selanjutnya dilakukan pengkategorisasian minat belajar siswa dalam mempelajari teknologi informasi dan komunikasi. Sudjono (Komariyah, Afifah, \& Resbiantoro, 2018) untuk mencari nilai dari kategorisasi angket minat disajikan pada Tabel 1.

Tabel 1

Kategori Pengelompokan Minat

\begin{tabular}{cc}
\hline Rentang Skor & Kategori \\
\hline $\mathrm{X}>(\mathrm{M}+\mathrm{SD})$ & Tinggi \\
$(\mathrm{M}-\mathrm{SD}) \leq \mathrm{X}<(\mathrm{M}+\mathrm{SD})$ & Sedang \\
$\mathrm{X}<\mathrm{M}-\mathrm{SD}$ & Rendah \\
\hline
\end{tabular}

Keterangan: $\mathrm{X}=$ Nilai Perhitungan, $\mathrm{M}=$ Nilai rata-rata (mean), dan $\mathrm{SD}=\mathrm{Standar}$ Deviasi

\section{HASIL PENELITIANDAN PEMBAHASAN}

Kemajuan TIK dalam segala hal membuat manusia semakin dimudahkan. Berbagai lembaga baik pemerintahan ataupun swasta, pendidikan, pelayanan kesehatan, transportasi telah memanfaatkan 
teknologi informasi dan komunikasi. Perubahan TIK yang sangat pesat membutuhkan proses adaptasi yang ketat. Manusia yang kreatif serta inovatif merupakan bekal yang diperlukan di zaman serba berkembang. Hal ini sejalan dengan penelitian Farah, Tarmizee, Abd Rahman, dan Zuraida (2018) yang menemukan bahwa dalam rangka menyongsong Abad 21 diperlukan kemampuan di antaranya kemampuan inovasi dan berpikir kreatif.

Salah satu bidang yang memperoleh dampak dari perkembangan TIK adalah dalam bidang pendidikan (Li, Yamaguchi, \& Takada, 2018; Pima, 2019). Siswa mampu beradaptasi dengan lingkungan di zaman teknologi informasi diperlukan peran guru. Peran guru sebagai fasilitator di dalam kelas menjadi hal yang paling peting karena setiap hari guru berinteraksi dengan siswa. Guru yang baik terus mengupayakan agar pembelajaran dikelas dapat berjalan dengan baik dan dapat menghasilkan hasil belajar yang baik. Hal ini sejalan dengan penelitian yang dilakukan Li et al. (2018) yang menemukan bahwa guru merupakan faktor utama yang dapat mempengaruhi siswa dalam penggunaan TIK pada saat pembelajaran.

Hasil belajar tidak hanya menyangkut ranah pengetahuan saja tetapi ranah sikap dan keterampilan. Ranah sikap mencakup tindakan menerima, menanggapi, menilai, organisasi, dan karakterisasi (Sönmez, 2017; Zeinabsadat, 2015). Ranah pengetahuan mencakup kemapuan mengetahui, pemahaman, aplikasi, analisis, dan sintesis. Ranah keterampilan mencakup ketertarikan, mengkontrol, menanggapi situasi, dan menciptakan. Untuk mencapai hasil belajar yang baik, terdapat berbagai faktor yang menjadi dorongan siswa meningkatkan kemampuan. Penelitian Li et al. (2018) menemukan bahwa salah satu bentuk dorongan dari diri siswa yang semestinya menjadi perhatian guru atau tenaga pengajar adalah minat belajar siswa. Siswa yang memiliki minat belajar tinggi akan terus berupaya mengembangkan kemampuannya, sedangkan siswa yang memiliki minat rendah cenderung tertinggal dalam pengembangan kemampuan. Pembelajaran yang menjadi fokus penelitian adalah pembelajaran tentang TIK di SMK. Kemampuan teknologi informasi dan komunikasi yang terus diasah pada tingkat SMK memiliki harapan agar siswa menyadari potensi yang ada pada dirinya. Selain itu, dengan adanya pembelajaran tentang TIK dapat meningkatkan minat siswa untuk terus mengembangkan dirinya sehingga siap menghadapi masa yang akan datang.

Penelitian ini dilakukan di SMK Negeri 3 Yogyakarta pada bulan Februari 2019. Data yang dianalisis pada penelitian ini berupa data angket minat belajar siswa terhadap pembelajaran teknologi informasi dan komunikasi dalam hal ini pada Mata Pelajaran Simulasi dan Komunikasi Digital kelas X SMK. Subjek penelitian adalah semua siswa kelas X Program Keahlian Teknik Komputer dan Jaringan (TKJ) di SMK Negeri 3 Yogyakarta dengan jumlah 30 siswa yang terdiri dari 4 siswa putri dan 26 siswa putra pada Tahun Ajaran 2018/2019.

Hasil penelitian diperoleh dari data minat belajar yang dianalisis dari data angket tentang minat belajar siswa ditinjau dari faktor internal. Faktor internal diamati berdasarkan pada tanggapan siswa mengenai kondisi fisiologis yaitu keadaan fisik dan psikologis yang berupa kecerdasan dan bakat seseorang yang mempengaruhi pada minatnya mengikuti pembelajaran teknologi informasi dan komunikasi. Data angket tentang minat belajar siswa ditinjau dari faktor eksternal yang berisi kondisi sosial dan nonsosial yang mempengaruhi 
minatnya belajar dalam hal ini belajar tentang teknologi informasi dan komunikasi. Kondisi sosial dan nonsosial ini terdiri dari lingkungan sekitar siswa seperti keluarga, teman, materi pembelajaran, ataupun kondisi tempat siswa belajar teknologi informasi dan komunikasi. Data angket dari pendekatan belajar. Pada bagian ini disajikan pertanyaan tentang cara mengajar guru dikelas sehingga materi yang menjadi tujuan pembelajaran dapat tersampaikan dengan baik. Dari hasil analisis diperoleh data statistik deskriptif yang disajikan pada Tabel 2.

Berdasarkan hasil analisis data, dilakukan pengkategorian berdasarkan analisis data distribusi frekuensi. Pengkategorisasian minat belajar siswa dibagi menjadi tiga bagian yaitu minat internal, minat eksternal, dan pendekatan belajar. Pada hasil analisis data minat internal, minat eksternal, dan pendekatan belajar dilakukan pengkategorian dalam tiga bentuk kategori yaitu kategori minat tinggi, sedang, dan rendah. Pengkategorian minat belajar bertujuan untuk mempermudah pengambaran minat yang ada pada diri seseorang. Dalam hal ini, pengkategorisasian dilakukan untuk mengetahui kategori minat siswa pada saat pembelajaran teknologi informasi dan komunikasi.

Hasil analisis statistik data minat internal siswa dalam pembelajaran teknologi informasi dan komunikasi diperoleh nilai rata-rata yaitu 63,1 ; nilai terendah 55 ; nilai tertinggi yaitu 75; dan Standar Deviasi 5,06. Nilai $(M+S D)=68,16$ dan nilai $(M-S D)$ $=58,03$. Tabel 3 merupakan gambaran distribusi frekuensi minat internal.

Berdasarkan analisis data minat internal dapat dilihat jika sebagian besar siswa memiliki minat yang sedang yaitu sebesar $66,66 \%$. Sebagian besar siswa dengan kategori sedang setuju untuk mengembangkan ketertarikannya dalam pembelajaran teknologi informasi dan komunikasi. Namun, banyak siswa tidak setuju untuk tidak mengalihkan perhatian

Tabel 2

Statistik Deskriptif Minat

\begin{tabular}{lccccc}
\hline Indikator & Jumlah & $\begin{array}{c}\text { Rata- } \\
\text { rata }\end{array}$ & $\begin{array}{c}\text { Standar } \\
\text { Deviasi }\end{array}$ & $\begin{array}{c}\text { Nilai } \\
\text { Terendah } \\
\text { (Min) }\end{array}$ & $\begin{array}{c}\text { Nilai } \\
\text { Tertinggi } \\
\text { (Maks) }\end{array}$ \\
\hline Internal & 1893 & 63,1 & 5,06 & 55 & 75 \\
Eksternal & 341 & 11,36 & 2,05 & 6 & 15 \\
Pendekatan Belajar & 361 & 12,03 & 1,51 & 8 & 15 \\
\hline
\end{tabular}

Tabel 3

Distribusi Frekunsi Minat Internal

\begin{tabular}{clcccc}
\hline \multirow{2}{*}{ No } & \multirow{2}{*}{ Kategori } & Rentang Skor & \multirow{2}{*}{ Frekuensi } & \multicolumn{2}{c}{ Prosentase } \\
\cline { 5 - 6 } & & & & Relatif & Kumulatif \\
\hline 1 & Tinggi & $75-69$ & 4 & $13,34 \%$ & $13,34 \%$ \\
2 & Sedang & $68-59$ & 20 & $66,66 \%$ & $80,00 \%$ \\
3 & Rendah & $58-55$ & 6 & $20 \%$ & $100 \%$ \\
\hline \multicolumn{2}{r}{ Total } & 30 & $100 \%$ & \\
\hline
\end{tabular}


pada saat pembelajaran berlangsung. Dengan kata lain, pada saat pembelajaran berlangsung siswa lebih tertarik dengan hal lain daripada pembelajaran yang sedang berlangsung, khususnya pembelajaran TIK. Komputer yang disediakan digunakan untuk hal lain selain pembelajaran. Fokus siswa dalam pembelajaran cenderung bercabang. Untuk mengatasi hal ini, guru tidak hanya berfokus pada materi yang disampaikan tetapi juga kesiapan siswa dalam memperoleh materi. Guru dapat memberikan himbauan untuk mematikan komputer pada saat pembelajaran berlangsung. Guru dapat memberikan umpan balik kepada siswa agar tetap fokus pada pembelajaran.

Selain itu, terdapat sebagian siswa yang tidak setuju untuk mendapatkan ilmu yang bermanfaat dalam pembelajaran teknologi informasi dan komunikasi. Hal ini berati sebagian besar siswa merasa aman dan kurang mengembangkan kemampuannya. Kesadaran akan manfaat pembelajaran yang didapat cenderung diabaikan. Sebagian besar siswa merasa bahwa menciptakan kesadaran pada dirinya masih belum diperlukan. Siswa cenderung mengerjakan yang menjadi tuntutan. Hal ini juga diperkuat dari pernyataan siswa dengan memilih menolak untuk diberi tugas yang sulit. Siswa menolak diberikan tugas yang sulit. Hal ini menandakan siswa kurang tertarik mengembangkan kemampuannya. Pemberian tugas yang sulit semestinya lebih mendorong siswa untuk terus mencoba memecahkan dan mengasah kemampuannya dengan terus mencari informasi terkait tugas yang diberikan.

Pada saat pembelajaran, masih banyak siswa setuju untuk lebih memilih diam daripada menanyakan dan mencari informasi terkait materi yang disampaikan. Dengan kata lain, pada saat memperoleh materi, siswa menjadi cenderung apa adanya tanpa mengembangkan pengetahuannya. Kesadaran siswa untuk mengembangkan pengetahuannya masih sangat diperlukan. Kesadaran untuk meningkatkan kemampuan dapat dilakukan guru dengan pemberian dorongan kepada siswa terkait masalah yang sedang menjadi perhatian siswa yaitu dengan memberikan gambaran tentang kehidupan yang akan datang dan peran ilmu yang sedang dipelajari di masa yang akan datang. Dilihat dari minat kategori tinggi, hanya sebagian kecil siswa yang memiliki minat internal yang tinggi yaitu sebesar $13,34 \%$. Dengan kata lain, minat siswa dari segi internal masih perlu ditingkatkan lagi mengingat persentase minat tinggi masih kecil.

Peringkat kedua adalah minat rendah yaitu sebesar $20 \%$. Hal ini sangat beresiko mempengaruhi siswa lain yang memiliki minat diatasnya. Jumlah siswa yang tidak setuju lebih banyak daripada siswa yang setuju untuk berperan aktif dalam pembelajaran. Berdasarkan pernyataan pada angket, sebagian besar siswa tidak setuju untuk berperan aktif dalam pembelajaran dan hanya sedikit siswa yang setuju untuk aktif dalam pembelajaran. Pembelajaran berjalan dengan baik apabila siswa dapat berperan aktif kegiatan pembelajaran. Keaktifan siswa dalam pembelajaran menjadi tanda besarnya ketertarikan siswa dalam pembelajaran. Selain itu, kesehatan pada diri menjadi hal yang perlu diperhatikan. Masih banyak siswa tidak setuju untuk menjaga kesehatan dengan rutin berolahraga. Fisik yang baik akan mudah menerima materi pelajaran yang berlangsung, khususnya pembelajaran teknologi informasi dan komunikasi.

Peningkatan minat perlu dilakukan siswa dengan harapan siswa tersebut lebih mengembangkan minat internal yang berupa kesadaran tentang fisiologis yag berupa kesadaran fisik dan psikologis yang 
berupa kecerdasan dan kemampuan siswa menghadapi sesuatu. Kesadaran fisiologis dibentuk dengan cara menumbuhkan kesadaran menjaga pola makan, waktu istirahat, dan kesehatan pada diri siswa agar pada saat pembelajaran berlangsung kondisi badan dalam keadaan yang baik. Contohnya, seorang siswa yang memiliki minat tinggi dalam pembelajaran, ia berusaha keras menjaga pola makan sehingga fokus menerima materi tanpa gangguan rasa lapar. Kondisi badan yang baik membuat materi yang didapat pada saat dipahami secara sempurna. Selanjutnya, untuk pembentukan kesadaran psikologis perlu dilakukan penumbuhan ketertarikan materi pada saat pembelajaran berlangsung. Guru memberikan materi dengan cara yang menarik setiap kali pertemuan agar siswa lebih tertarik dalam pembelajaran. Dengan pemberian materi yang menarik, siswa akan menfokuskan perhatian secara sukarela dalam pembelajaran. Secara tidak sadar, perhatian siswa tersebut dapat meningkatkan kualitas hasil belajar pada proses pembelajaran yaitu pembelajaran teknologi informasi dan komunikasi.

Hasil penelitian ini sejalan dengan penelitian Nurhasanah dan Sobandi (2016) yang menyimpulkan bahwa perhatian dan ketertarikan dalam pembelajaran dipengaruhi oleh minat siswa dalam pembelajaran sehingga pembelajaran dapat optimal. Selain perhatian dan ketertarikan dalam pembelajaran, minat siswa juga dipengaruhi oleh motivasi belajar dan pegetahuan yang siswa miliki tentang materi yang didapat saat pembelajaran. Selanjutnya, penelitian yang dilakukan Pambudi (2015) yang menyimpulkan kondisi fisik pada saat pembelajaran berlangsung mempengaruhi hubungan yang signifikan terhadap prestasi belajar yaitu sebesar 50,8\%. Siswa menjaga kondisi fisik agar siswa dapat memperoleh prestasi yang memuaskan pada saat pembelajaran berlangsung.

Data yang dianalisis adalah berupa data minat eksternal. Berdasarkan analisis statistik data minat eksternal siswa dalam pembelajaran teknologi informasi dan komunikasi diperoleh; nilai rata-rata yaitu 11,36 , nilai terendah 6 , nilai tertinggi yaitu 15, dan Standar Deviasi 2,05. Nilai $(\mathrm{M}+\mathrm{SD})=13,41$ dan nilai $(\mathrm{M}-\mathrm{SD})=$ 9,31. Distribusi frekuensi minat eksternal disajikan pada Tabel 4.

Berdasarkan data hasil analisis diperoleh bahwa pada minat eksternal, sebagian besar siswa memiliki minat yang sedang yaitu sebesar $66,66 \%$. Siswa yang memiliki minat tinggi dan rendah seimbang yaitu sebesar 16,67\%. Kategori minat tinggi masih amat kecil. Masih terdapat banyak siswa yang tidak setuju bahwa keluarga berperan dalam penumbuhan minat. Siswa beranggapan bahwa pada saat pembelajaran berlangsung keluarga belum memberikan

Tabel 4

Distribusi Frekuensi Minat Eksternal

\begin{tabular}{|c|c|c|c|c|c|}
\hline \multirow{2}{*}{ No } & \multirow{2}{*}{ Kategori } & \multirow{2}{*}{ Rentang Skor } & \multirow{2}{*}{ Frekuensi } & \multicolumn{2}{|c|}{ Prosentase } \\
\hline & & & & Relatif & Kumulatif \\
\hline 1 & Tinggi & $15-14$ & 5 & $16,67 \%$ & $16,67 \%$ \\
\hline 2 & Sedang & $13-10$ & 20 & $66,66 \%$ & $83,33 \%$ \\
\hline 3 & Rendah & $9-6$ & 5 & $16,67 \%$ & $100 \%$ \\
\hline \multicolumn{3}{|c|}{ Total } & 30 & $100 \%$ & \\
\hline
\end{tabular}


pengaruh yang banyak. Siswa merasa belum terlalu paham manfaat yang diperoleh ketika mengikuti pembelajaran dengan sungguh-sungguh dapat berdampak pada nasib keluarga di masa yang akan datang. Peran teman-teman sebaya dalam kelas juga belum memberikan dampak yang baik dalam peningkatan minat belajar. Siswa menjawab tidak sejutu pada pernyataan teman mempengaruhinya untuk lebih giat belajar. Iklim lingkungan kelas yang bersaing masih kurang. Dapat dikatakan jika teman sekelas belum memberikan pengaruh yang berarti dalam peningkatan minat pada saat pembelajaran teknologi informasi dan komunikasi.

Selain itu, masih terdapat siswa yang tidak setuju bahwa sumber belajar membuatnya tertarik dalam pembelajaran. Pembelajaran cederung membosankan dan tidak berpengaruh banyak. Berdasarkan pernyataan siswa dapat dikatakan bahwa sebagian siswa beranggapan lingkungan sosial dan nonsosial seperti keluarga, sekolah, masyarakat, ataupun materi yang diperoleh pada saat pembelajaran belum berpengaruh dalam pengembangan minat. Hal ini dapat dilihat juga dari hasil analisis bahwa masih ada siswa yang memiliki minat rendah. Pengembangan dan dukungan lingkungan diharapkan dapat meningkatan minat belajar siswa dalam mempelajari materi, khususnya materi tentang teknologi informasi dan komunikasi.

Kerja sama yang baik antara pihak sekolah dan keluarga untuk meningkatkan minat perlu dilakukan. Sekolah dan keluarga memberikan gambaran tentang manfaat masa depan diharapkan dapat membuat siswa lebih tertantang untuk meningkatkan kemampuannya. Dengan demikian, minat yang ada pada diri siswa akan meningkat. Selain itu, guru yang baik dapat menghubungkan sumber-sumber belajar yang berupa materi pembelajaran dengan kondisi yang hangat atau yang sedang ramai dibincangkan. Sebagai contoh dalam pembelajaran teknologi informasi dan komunikasi, guru memberikan gambaran awal tentang perkembangan teknologi yang mengakibatkan manusia menginginkan kemudahan. Kemudian, menggambarkan inovasi e-book yang membuat seseorang dimudahkan. Saat ini, pengembang dari e-book masih sedikit atau sangat kurang. Dengan contoh tersebut, kesadaran siswa untuk belajar teknologi informasi dan komunikasi akan terpupuk. Siswa lebih antusias dalam mengikuti pembelajaran di sekolah karena masalah yang dihadapi sangat dibutuhkan untuk saat ini dan masa yang akan datang.

Hasil penelitian ini sejalan dengan penelitian yang dilakukan Palangda (2017) yang menyatakan bahwa terdapat pengaruh positif antara minat belajar dengan lingkungan yang ada di sekitar siswa. Lingkungan yang dimaksud adalah lingkungan keluarga dan lingkungan sekolah. Data minat dianalisis berdasarkan pendekatan belajar yang digunakan dalam pembelajaran. Berdasarkan analisis statistik data, data pendekatan belajar pada minat belajar siswa dalam pembelajaran teknologi informasi dan komunikasi diperoleh nilai rata-rata yaitu 12,03 ; nilai terendah 8 ; nilai tertinggi yaitu 15; dan Standar Deviasi 1,51. Nilai $(\mathrm{M}+\mathrm{SD})=13,55$ dan nilai $(\mathrm{M}-\mathrm{SD})$ $=10,51$. Tabel 5 menyajikan distribusi frekuensi minat eksternal.

Dari hasil analisis dapat dilihat jika sebagian besar siswa memiliki minat yang sedang yaitu sebesar $70 \%$ atau sejumlah 21 siswa. Hal ini sangat perlu ditingkatkan. Semakin pesat teknologi membuat seseorang harus terus belajar dan berkembang. Berdasarkan data yang diperoleh pada saat penelitian masih terdapat siwa tidak setuju bahwa pada saat pembelajaran berlangsung guru menggunakan model/ 
Tabel 5

Distribusi Frekuensi Minat Eksternal

\begin{tabular}{|c|c|c|c|c|c|}
\hline \multirow{2}{*}{ No } & \multirow{2}{*}{ Kategori } & \multirow{2}{*}{ Rentang Skor } & \multirow{2}{*}{ Frekuensi } & \multicolumn{2}{|c|}{ Prosentase } \\
\hline & & & & Relatif & Kumulatif \\
\hline 1 & Tinggi & $15-14$ & 4 & $13,33 \%$ & $13,33 \%$ \\
\hline 2 & Sedang & $13-11$ & 21 & $70 \%$ & $83,33 \%$ \\
\hline 3 & Rendah & $10-8$ & 5 & $16,67 \%$ & $100 \%$ \\
\hline \multicolumn{3}{|c|}{ Total } & 30 & $100 \%$ & \\
\hline
\end{tabular}

metode pembelajaran yang menarik. Pembelajaran menjadi membosankan dan siswa tidak tertarik mengikuti pembelajaran dikarenakan guru tidak menginovasi model pembelajaran. Peningkatan minat belajar berdasarkan pendekatan belajar dapat dilakukan dengan memberikan inovasi baru terhadap pembelajaran.

Sejalan pada saat dilakukan observasi, sebagian besar siswa berpendapat jika guru kurang menginovasi pembelajarannya. Pada saat pembelajaran berlangsung, guru lebih membekali siswa terhadap teoriteori tentang teknologi informasi dan komunikasi. Penyampaian informasi terkait materi yang diajarkan masih menggunakan media yang minim seperti slide persentasi. Informasi yang diterima pun sebagian besar mengacu pada ranah pengetahuan. Keterampilan untuk menciptakan hal baru pada saat pembelajaran teknologi dan informasi masih sangat minim. Dengan kata lain, siswa setuju agar guru meningkatkan model/metode pembelajaran. Untuk menambah wawasan bagi guru, perlu dilakukan pelatihan atau diklat khusus agar pembelajaran lebih inovatif, menarik, dan efektif.

Pembelajaran yang menarik dapat dilakukan dengan mengkolaborasi pembelajaran dengan model-model pembelajaran yang sesuai dengan pokok bahasan sehingga siswa lebih antusias dalam pembelajaran. Antusias siswa yang meningkat dapat meningkatkan hasil belajar. Penerapan model/metode pembelajaran secara tidak sadar dapat meningkatkan kualitas dan relevansi pembelajaran.

Hasil penelitian ini sejalan dengan penelitian yang dilakukan Nurfazar, Rokhayati, dan Lidinillah (2016) yang menyatakan bahwa minat belajar siswa yang mendapat perlakuan dengan metode pembelajaran dramath lebih besar dibandingkan dengan minat belajar siwa yang tidak mendapat perlakuan dengan model/metode dramath. Dengan kata lain, metode/model pembelajar berpengaruh terhadap hasil yang didapat pada saat pembelajaran berlangsung.

Selain itu, peningkatan suasana kelas yang kondusif juga perlu ditingkatkan. Sebagian besar siswa setuju untuk meningkatkan suasana yang kondusif. Suasana yang kondusif membuat siswa nyaman mengikuti pembelajaran. Selain itu, suasana yang kondusif memudahkan siswa memperoleh materi yang disampaikan pada saat pembelajaran teknologi informasi dan komunikasi. Perlu adanya peran aktif guru bersama siswa untuk meningkatkan suasana yang kondusif tersebut.

Jumlah persentase tertinggi peringkat kedua adalah kategori minat rendah yaitu sebesar 16,67\% dan kategori dengan persentase paling kecil adalah kategori tinggi yaitu sebesar 13,33\%. Dengan 
kata lain, indikator minat pendekatan belajar menjadi masalah yang serius dan memerlukan penanganan yang berati dan segera agar siswa lebih menumbuhkan ketertarikan saat mengikuti pembelajaran teknologi informasi dan komunikasi.

Keseluruhan hasil penelitian di atas menujukan bahwa peningkatan minat belajar dalam pembelajaran teknologi informasi dan komunikasi sangat perlu dilakukan. Minat yang baik berpotensi meningkatkan hasil belajar. Hasil penelitian ini sejalan dengan beberapa penelitian terdahulu yang berujung pada kesimpulan peningkatan minat belajar dapat dilakukan untuk menumbuhkan kesadaran pentingnya minat pada siswa pada pembelajaran teknologi informasi dan komunikasi. Minat yang baik akan mempengaruhi prestasi belajar pada saat pembelajaran berlangsung (Nurhasanah \& Sobandi, 2016; Pambudi, 2015). Penelitian Sirait (2016) menyimpulkan bahwa terdapat hubungan yang signifikan antara minat belajar terhadap presetasi belajar yaitu sebesar $49,8 \%$. Penelitian yang dilakukan Palangda (2017) yang menyatakan bahwa terdapat pengaruh positif antara minat belajar dengan lingkungan. Lingkungan yang dimaksud adalah lingkungan keluarga dan lingkungan sekolah.

\section{SIMPULAN}

Berdasarkan hasil penelitian dan pembahasan dapat disimpulkan bahwa pembelajaran teknologi informasi dan komunikasi bagi siswa kelas X SMK ditinjau dari minat belajar perlu ditingkatkan. Perlu ada penangan serius antara sekolah berkerja sama dengan keluarga untuk meningkatkan minat siswa dalam pembelajaran teknologi informasi dan komunikasi. Sebagian besar siswa masih memiliki minat yang sedang dalam mempelajari teknologi informasi dan komunikasi. Minat sedang cenderung membuat siswa lebih santai dan kurang mengembangkan kemampuannya.

Ditinjau dari minat internal sebagian besar siswa memiliki minat sedang. Hal ini berati sebagian besar siswa merasa aman dan kurang mengembangkan kemampuannya. Hanya sebagian kecil yang memiliki minat internal yang tinggi. Minat tinggi ini memiliki persentase paling kecil dibandingkan dengan kategori lainya. Hanya sebagian kecil siswa merasa ketertarikan yang tinggi pada pembelajaran. Dengan kata lain, minat siswa dari segi internal masih perlu ditingkatkan lagi mengingat persentase minat kategori tinggi masih kecil. Peringkat kedua diduduki pada minat rendah. Hal ini sangat berisiko mempengaruhi siswa lain yang memiliki minat diatasnya. Peningkatan minat perlu dilakukan agar siswa lebih mengembangkan minat internal yang berupa kesadaran tentang fisik dan psikologis yang berupa kecerdasan dan kemampuan siswa meng-hadapi sesuatu.

Kesadaran pada minat internal dapat dilakukan dengan mendukung agar menjaga kesehatan dan kebersihan fisik yang berupa raga sedangkan untuk menumbuhkan kesadaran psikologis dapat dilakukan dengan pengarahan siswa untuk sadar akan teknologi informasi dan komunikasi agar mampu bertahan di masa selanjutnya. Ditinjau dari minat eksternal, sama seperti minat internal. Sebagian besar siswa memiliki minat yang sedang. Siswa yang memiliki minat tinggi dan rendah seimbang. Kategori minat tinggi masih amat kecil. Sebagian siswa beranggapan bahwa lingkungan sosial dan nonsosial seperti keluarga, sekolah, masyarakat, ataupun materi yang diperoleh pada saat pembelajaran belum berpengaruh dalam pengembangan minatnya. Hal ini dapat dilihat juga dari data hasil analisis bahwa masih ada siswa yang memiliki minat rendah. Pengembangan dan dukungan lingkungan diharapkan dapat meningkatan minat siswa 
dalam mempelajari materi, khususnya materi tentang teknologi informasi dan komunikasi. Pada minat eksternal perlu adanya kesadaran dari lingkungan untuk mendukung perkembangan minat siswa yang dapat berpengaruh di masa depan. Akan tetapi, pengaruh lingkungan tidak dapat diubah dengan mudah. Setiap manusia memiliki karateristik sendiri-sendiri. Perlu adanya kesadaran yang matang dari setiap anggota dalam lingkungan untuk sadar teknologi.

Selanjutnya, ditinjau dari pendekatan belajar sebagian besar siswa memiliki minat yang sedang. Dengan kata lain, peningkatan minat belajar dengan pendekatan belajar sangat perlu ditingkatkan. Semakin pesat teknologi membuat seseorang harus berkembang. Peningkatan kemampuan siswa dapat dilakukan dengan memberikan suguhan atau tantangan yang baru. Sebagian besar siswa berpendapat jika guru kurang menginovasi pembelajaran. Informasi yang diterima siswa pada saat pembelajaran sebagian besar mengacu pada ranah pengetahuan. Keterampilan untuk menciptakan hal baru pada saat pembelajaran teknologi dan informasi masih perlu ditingkatkan. Untuk mengatasi masalah tersebut, perlu adanya kegiatan untuk menambah wawasan guru yaitu dengan diadakan diklat atau pelatihan khusus agar pembelajaran lebih inovatif, menarik, dan efektif.

Pembelajaran yang menarik dapat dilakukan dengan menerapkan berbagai model pembelajaran sehingga siswa lebih antusias. Jumlah persentase tertinggi kedua pada pendekatan belajar pada kategori minat rendah dan kategori dengan persentase paling kecil adalah kategori tinggi. Dengan kata lain, indikator minat pendekatan belajar menjadi masalah yang serius dan memerlukan penanganan yang berarti agar siswa lebih tertarik mengikuti pembelajaran teknologi informasi dan komunikasi.

\section{DAFTAR PUSTAKA}

Anshori, S. (2017). Pemanfaatan TIK sebagai sumber dan media pembelajaran di sekolah. Jurnal Ilmu Pendidikan PKN \& Sosial Budaya, 1(1), 10-20. Diunduh dari http://jurnal.stkippgri-bkl.ac.id/ index.php/CC/article/view/84.

Farah, R. N., Tarmizee, M., Abd Rahman, K., \& Zuraida, R. L. (2018). Orthogonal Projector Kit (OPK) as a new teaching aids with innovation ICT in Teaching and Learning $21^{\text {st }}$ Century. Journal of Fundamental and Applied Sciences, 10(3S), 338-344.

Komariyah, S., Afifah, D. S. N., \& Resbiantoro, G. (2018). Analisis pemahaman konsep dalam memecahkan masalah matematika ditinjau dari minat belajar siswa. SOSIOHUMANIORA: Jurnal Ilmiah Ilmu Sosial Dan Humaniora, 4(1).

Muhson, A. (2009). Upaya peningkatan minat belajar dan pemahaman mahasiswa melalui penerapan problembased learning. Jurnal Kependidikan: Penelitian Inovasi Pembelajaran 39(2), 171-182. Diunduh dari https:// journal.uny.ac.id/index.php/jk/article/ view/62.

Nurfazar, S., Rokhayati, A., \& Lidinillah, D. A. M. (2016). Pengaruh metode dramath terhadap minat belajar siswa sekolah dasar dalam pembelajaran matematika. PEDADIDAKTIKA: Jurnal Ilmiah Pendidikan Guru Sekolah Dasar, 3(1), 129-137.

Nurhasanah, S., \& Sobandi, A. (2016). Minat belajar sebagai desterminan hasil belajar siswa. Jurnal Pendidikan Manajemen Perkantoran, 1(1), 128135. 
Nurmala, S. (2012). Faktor-faktor yang mempengaruhi minat siswa untuk melanjutkan ke Sekolah Menengah Kejuruan. Jurnal Kependidikan: Penelitian Inovasi Pembelajaran 42 (2), 162-172. Diunduh dari https:// journal.uny.ac.id/index.php/jk/article/ view/1950.

Palangda, L. (2017). Pengaruh lingkungan sekolah dan lingkungan keluarga terhadap minat belajar ekonomi peserta didik di SMKN 4 Makasar (Tesis tidak diterbitkan). Universitas Negeri Makassar, Makassar.

Pambudi, A. M. A. (2015). Keterkaitan kondisi fisik dengan prestasi belajar penjasorkes pada siswa yang mengikuti ektrakurikuler futsal. Jurnal Kesehatan Olahraga, 2(3), 117-123.

Pima, J. (2019). Factors that motivate teachers to use ICT in teaching: A case of Kaliua District secondary schools in Tanzania. International Journal of Education and Development using ICT, 15(1).

Kawet, R. S. I. (2017). Pengaruh metode pembelajaran dan minat belajar mahasiswa terhadap hasil belajar manajemen konstruksi. Jurnal Teknologi Pendidikan, 19(3), 224-239.

Rusyan, T. (2015). Seri peningkatan mutu pendidikan: Membangun guru berkualitas. Jakarta: Intimedia Ciptanusantara.

Li, S., Yamaguchi, S., \& Takada, J-I. (2018). Understanding factors affecting primary school teachers' use of ICT for student-centered education in Mongolia. International Journal of Education and Development using
Information and Communication Technology (IJEDICT), 14(1), 103-117. Diunduh dari http://ijedict.dec.uwi. edu/viewissue. php?id=50\#Refereed Articles.

Sirait, E. D. (2016). Pengaruh minat terhadap prestasi belajar matematika. Jurnal Formatif, 6(1), 35-43.

Slameto. (2009). Belajar dan faktor-faktor yang mempengaruhinya. Jakarta: PT Rineka Cipta.

Suparman, M. A. (2014). Desain instruksional modern. Jakarta: Penerbit Erlangga.

Surifah, Mustiati, E., Syaifullah, M. Z., \& Bowo, A. N. A. (2016). Pengaruh motivasi terhadap minat mahasiswa mengikuti pendidikan profesi akuntansi. Jurnal Kependidikan: Penelitian Inovasi Pembelajaran, 42(2), 246-258. Diunduh dari https:// journal.uny.ac.id/index.php/jk/article/ view/9615.

Sönmez, V. (2017). Association of cognitive, affective, psychomotor and intuitive domains in education, Sönmez model. Universal Journal of Educational Research, 5(3), 347-356. DOI: 10.13189/ujer.2017.050307.

Zeinabsadat. (2015). Case Studies in Three Domains of Learning: Cognitive, Affective, Psychomotor. International Journal of Social, Behavioral, Educational, Economic, Business and Industrial Engineering 9(21042107). Dari: https://publications. waset.org/10002130/case-studies-inthree-domains-of-learning-cognitiveaffective-psychomotor. 